\title{
Materials Based on Chitosan and Polylactide: From Biodegradable Plastics to Tissue Engineering Constructions
}

\author{
T. S. Demina ${ }^{a} *$, T. A. Akopova ${ }^{a}$, and A. N. Zelenetsky ${ }^{a}$ \\ ${ }^{a}$ Enikolopov Institute of Synthetic Polymeric Materials, Russian Academy of Sciences, Moscow, 117393 Russia \\ *e-mail:detans@gmail.com \\ Received April 13, 2021; revised June 8, 2021; accepted June 21, 2021
}

\begin{abstract}
The transition to green chemistry and biodegradable polymers is a logical stage in the development of modern chemical science and technology. In the framework of this review, the advantages, disadvantages, and potential of biodegradable polymers of synthetic and natural origin are compared using the example of polylactide and chitosan as traditional representatives of these classes of polymers, and the possibilities of their combination via obtaining composite materials or copolymers are assessed. The mechanochemical approach to the synthesis of graft copolymers of chitosan with oligolactides/polylactides is considered in more detail.
\end{abstract}

DOI: $10.1134 / \mathrm{S} 1811238221020028$

\section{INTRODUCTION}

The modern chemical industry is aiming at a shift toward environmental management, green chemistry, and biodegradable or recyclable materials. Taking into account the inertness of large-scale production and, at the same time, the necessity to change equipment for more expensive at the first (possibly transitional) stage it seems rational to look for methods and approaches to regulate the service life of already used large-scale polymers and their efficient processing, but the future, most likely, belongs to biodegradable polymers. At a minimum their share in the total polymer production should increase over time. Available biodegradable polymers include synthetic polyesters and natural polysaccharides. One of the most famous and promising polyesters is polylactide [poly(lactic acid)], and chitosan can be distinguished among polysaccharides. This is the product of deacetylation of natural chitin which is the second most common polysaccharide after cellulose with a set of promising properties. This review is intended to assess the potential of using the above polymers in various fields and their combination methods to create biodegradable materials with a wide range of functional properties and using modern technologies for molding products.

\section{POLYLACTIDE: SYNTHESIS, PROPERTIES, AND APPLICATION}

According to a survey by Grand View Research published in March this year, the production of polylactide is showing steady growth in all areas of its application, such as packaging, textiles, transporta- tion, agricultural, and other industries. A number of articles, reviews, and books are devoted to the production, modification, and use of polylactide materials [1-7]. Within the framework of this review, we will only outline the key points from our point of view that are associated with the production, properties, and use of polylactide materials. A significant advantage of polylactide is that lactic acid needed for its production can be produced by the enzymatic method which increases the environmental prospects of this polymer $[1,8,9]$. In this case, both $L(+)$ - and $D(-)$-lactic acid can be obtained. The synthesis of polylactide from various stereoisomers allows one to obtain polymers with different stereoregularities and, accordingly, properties. The polycondensation of lactic acid yields for the most part low molecular weight oligomers which are further used for the synthesis of the cyclic dimer of lactic acid, lactide. The ring-opening polymerization of lactide results in a high molecular weight polylactide. The use of catalysts, azeotropic solvents, and additional polymerization also enables one to synthesize high molecular weight polylactide $(M \geq 3 \times$ $10^{5}$ ) directly from lactic acid [10]. The improvement of technologies for the synthesis of polylactide makes it possible to increase its production and reduce the cost.

Semicrystalline poly $(L, L$-lactide) is used more widely than amorphous $D, L$-isomer. This is associated with the possibility to manufacture durable materials with a sufficiently long service life which can be several years and vary widely depending on the structure of the material and the conditions of degradation. The ability to crystallize is purposefully suppressed to impart plasticity to polylactide materials, the absence 
of which in the case of samples with a high degree of crystallinity limits the processing of polylactide and the use of polylactide-based materials. This is important, for example, if polylactide is intended for use in additive technologies or for producing materials with a shorter service life [11]. From the technological point of view the simplest and most effective way is to introduce plasticizers (monomers/oligomers of polylactide, glycerol, PEG). To solve biomedical problems, in most cases, biodegradable materials are needed (from self-absorbable suture materials to tissue engineering scaffolds) with a service life of up to several months. This is achieved by using amorphous poly $(L, D$-lactide) and its copolymers with polyglycolide or polycaprolactone. A variety of pathways for the synthesis of polylactide and the possibility to regulate its enantiomeric composition and MW determine a large set of polymers and oligomers of lactide suitable for manufacturing materials for various purposes.

The successful use of polylactide for molding materials on its basis is also associated with the availability of technologies for its processing. Being a thermoplastic with a glass transition temperature of $\sim 60^{\circ} \mathrm{C}$ and a melting point of $\sim 160^{\circ} \mathrm{C}$ (in case $L, L$-polylactide or $D, D$-polylactide) polylactide is suitable for most melt technologies: injection molding, extrusion blow molding, and 3D printing. For specific methods of additive technologies it may be necessary to synthesize polylactide with additionally introduced functional groups [12].

The disadvantages of polylactide-based products can be attributed to their relatively low glass transition temperature which is not very convenient, for example, for the production of packaging materials [13]. The application of polylactide in medicine encounters another problem related to the inertness of its surface which leads to a poor adhesion of animal cells when they are cultivated in vitro or when a polylactide material is implanted into the body in vivo. [14]. Nevertheless, polylactide materials are widely used in medicine as a means of targeted and/or prolonged delivery of drugs [15-18], micro-/nanofiber materials [19-21], and scaffolds for tissue engineering [11, 21-23]. Modern functional materials based on polylactide are generally composite ones [24-28].

\section{CHITOSAN: PREPARATION, STRUCTURE, AND APPLICATION}

Biodegradable natural polymers, including polysaccharides, have a number of advantages that determine their important place in the polymer industry. In addition to their natural origin and biodegradability, it is important that many polysaccharides are waste treatment products; therefore, their use can be fully attributed to the category of rational environmental management. For example, tons of chitin, the second most abundant polysaccharide in nature after cellulose, which is found in the greatest amount in the composition of arthropod exoskeletons, is thrown into the sea without processing after crustaceans are caught [29-32].

Chitin, $\operatorname{poly}(N$-acetylglucosamine $)$, is slightly soluble in concentrated inorganic acids and in some mixed organic solvents which limits its use. The product of its deacetylation, chitosan, contains at least $60 \%$ units with a primary amino group; therefore, it dissolves well in dilute aqueous solutions of monobasic organic and inorganic acids [33, 34]. In industry, chitosan is obtained by the alkaline deacetylation of chitin under heterogeneous conditions with a $50 \% \mathrm{NaOH}$ solution at $70-100^{\circ} \mathrm{C}$ for $10 \mathrm{~h}$ or more [29]. A degree of deacetylation of 0.75 is sufficient to obtain chitosan with a high solubility, although the repeated alkaline deacetylation of chitin yields samples with a degree of deacetylation (DD) of 0.99 .

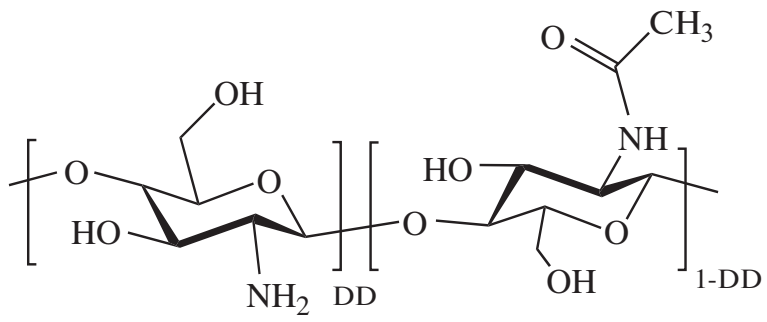

A mechanochemical approach based on solid-state reactive blending of chitin with an alkali in a one-stage extrusion process makes it possible to produce chitosan with the degree of deacetylation $\geq 0.9$ at a fivefold molar excess of sodium hydroxide which is significantly lower than that used in traditional suspension processes. In this case, the duration of the synthesis is reduced from hours to several minutes which determines high economic and environmental indicators of such a process $[35,36]$. Chitosan deacetylated by the solid-phase method has a lower $\operatorname{MW}\left(\sim 10^{5}\right)$.

The structure of chitosan macromolecules (the number of residual chitin units and their distribution along chain), like their molecular weight, can vary within wide limits; however, unlike polylactide, it is rather difficult to control, since it is the result not of targeted synthesis but of characteristics of the initial chitin and conditions for its isolation from natural raw materials and subsequent deacetylation [30]. The molar content of the main units of chitosan (glucosamine) is characterized by the degree of deacetylation and, like MW, significantly affects the properties of chitosan [29]. The content and distribution of residual $N$-acetylglucosamine units along the main chain determine not only the solubility of chitosan in aqueous media and its physicochemical properties, including the degree of crystallinity, but also such characteristics as bactericidal, bacteriostatic, and antiviral activity and rate of enzymatic hydrolysis [37-40]. The degree of crystallinity and the type of crystalline fraction of chitosan also depend on the source of isolation and method of obtaining the polysaccharide, MW, 
and the degree of deacetylation. Chitosan macromolecules form a strong system of intramolecular and intermolecular hydrogen bonds which impart rigidity to the polymer chain; as a result, their melting point is higher than the decomposition temperature. Consequently, the formation of materials based on chitosan is possible only from its solutions. Protonated chitosan, in contrast to chitosan in the form of a free base, dissolves in water, but at $\mathrm{pH}$ of about $6.0-6.5$ the polymer begins to precipitate. There are salts of chitosan and formic, acetic, mono-, di-, and trichloroacetic, hydrochloric, nitric, and other monobasic acids.

The areas of application of chitosan include ecology, water treatment processes, and agriculture. This is due to its high sorption capacity for active radicals and heavy metal ions [41-46]. The bacteriostatic activity of chitosan determines the interest in it in the production of packages [32, 37, 39, 47-49]. But the largest amount of publications concerns the use of chitosan in biomedicine as components of drug delivery and/or prolonged release systems, dressings, or scaffolds for tissue engineering [40, 50-62]. In practice, the use of chitosan is limited by the problems of its standardization and low hemocompatibility which does not prevent its use as dressings but does not allow its application as implants [63, 64]. Biodegradation of chitosan in vivo owing to its enzymatic hydrolysis by lysozyme, a nonspecific proteolytic enzyme present in all tissues of the body, and its good biocompatibility explain the unremitting interest in it from biomedicine. Chitosan has good film- and fiber-forming properties; it is successfully used to form hydrogels of various morphologies and micro-/nano-sized particles [54, 65-71]. As in the case of polylactide, significant efforts are being made to regulate and improve the properties of chitosan-containing materials by combining chitosan with other components or by modifying the chemical structure [72]. In the latter case, its derivatives or copolymers are synthesized using both hydroxyl and amine groups as reaction centers [36, 73-82].

\section{COMPOSITE MATERIALS BASED ON POLYLACTIDE AND CHITOSAN}

A significant number of works is devoted to composite materials based on polylactide and chitosan. Both polymers are recognized as promising candidates for the creation of biodegradable materials that successfully combine the properties of synthetic and natural components. The basic idea is that polylactide is convenient from the technological point of view, and materials based on it have high mechanical characteristics, but high hydrophobicity and, as a consequence, the duration of hydrolysis in the environment and in the body and low adhesion to cell cultures limits its application for solving environmental (creation of biodegradable materials) and medical (scaffolds for tissue engineering) tasks which can compensate for chitosan when combining these polymers in one product.

The problem of increasing biocompatibility of a material is often reduced to applying a chitosan coating on a polylactide article. However, the use of polylactide materials as implants for regenerative medicine almost always requires modifying their surface before applying bioactive coatings. It can be carried out by various methods, including laser and $\gamma$ irradiation and plasma processing [83, 84]. The second approach includes a simple mixing of chitosan with polylactide [85-90].

\section{COPOLYMERS OF CHITOSAN WITH POLYLACTIDE AND MATERIALS BASED ON THEM}

It is difficult to combine both components under melt conditions owing to the infusibility of chitosan; therefore, their mixing in the melt leads to the production of an inhomogeneous composite material in which chitosan particles remain unchanged in size (at least $5 \mu \mathrm{m}$ ) and the fraction of the graft fraction is minimal [91]. The combination of the advantages of polylactide and chitosan in one macromolecule can provide homogeneous materials with a set of valuable properties and enhanced moldability and processability. Reactions carried out in solutions make it possible to synthesize the graft copolymers of chitosan with oligolactides, but this requires that the process be performed via several stages, the intermediate products be isolated, and the solvents and process catalysts (isocyanates, dibutyltin dilaurate, $\left.\mathrm{Ti}(\mathrm{OBu})_{4}, \mathrm{SnCl}_{4}, \mathrm{LiCl}\right)$ be used. In this case, the achieved degree of polymerization of grafted oligolactide fragments is low [92-98]. The graft copolymers of chitosan with oligolactide were synthesized under sonication, and the results seem promising [99]. Environmental prospects and overall productivity of such approaches at this stage of development are insufficient for scaling up processes to manufacture materials based on the synthesized copolymers.

Within the framework of our review, we consider it expedient to dwell in more detail on the mechanochemical approach to the synthesis of graft copolymers of chitosan with oligolactides/polylactides. Solid-state reactive blending in a twin-screw extruder makes it possible with high productivity to synthesize chitosan copolymers containing oligolactide/polylactide fragments of various length and stereochemical composition without the use of catalysts and solvents. First, this method of modifying chitosan is more ecofriendly; secondly, the possibility of avoiding the use of catalysts and solvents at the stage of synthesis makes such copolymers safer from the point of view of their further use in biomedicine; and, third, the productivity of the method ensures transition to the industrial scale production and provides a sufficient amount of copolymers to manufacture materials on their basis. 

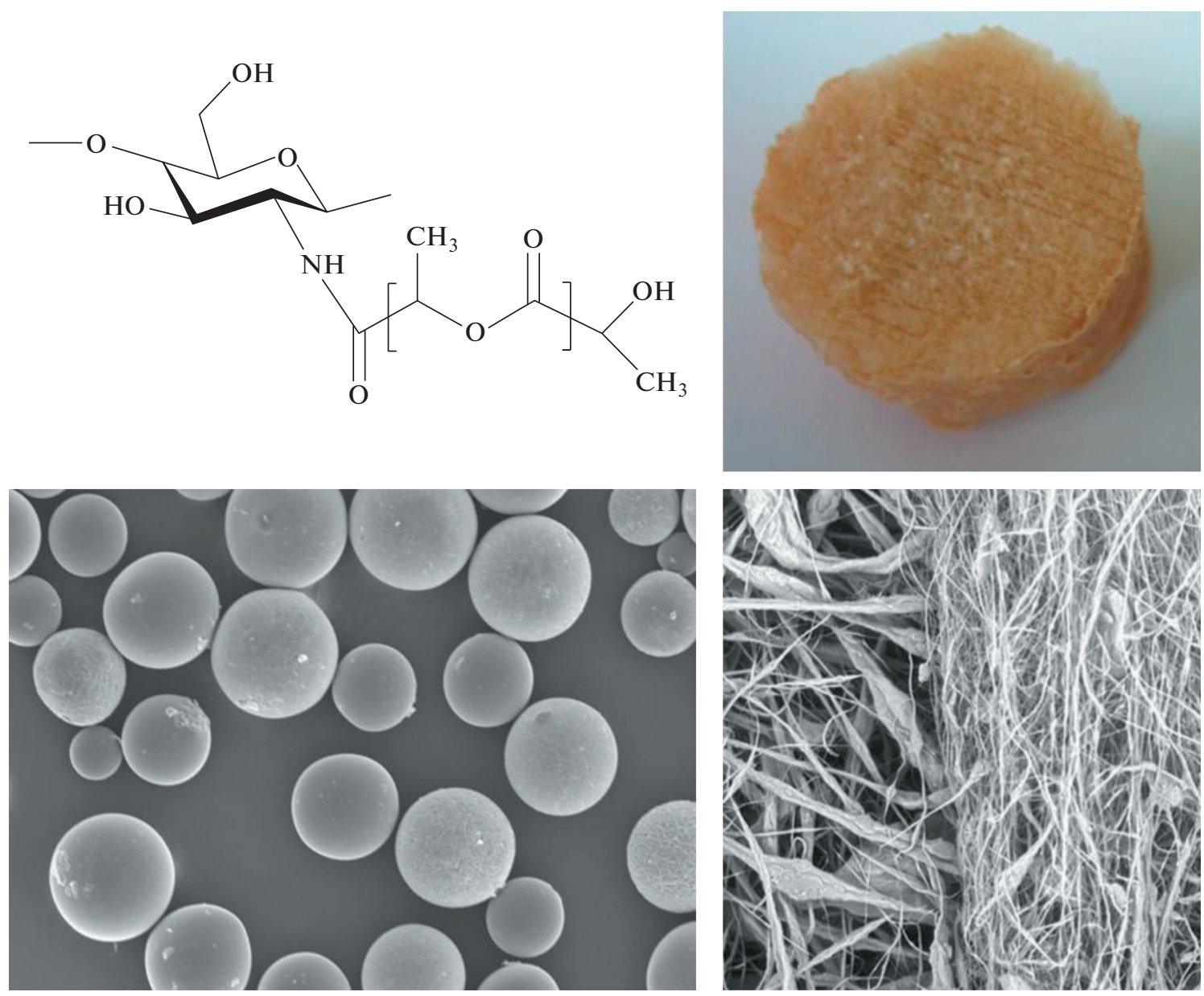

Fig. 1. Chemical structure of the elementary unit and materials based on the copolymers of chitosan with oligoesters/polyesters.

Oligomeric chains of $D, L$-lactide were grafted on chitosan by solid-state synthesis via coextruding solid mixtures of chitosan and $D, L$-lactide at various ratios of components and temperatures $\left(90^{\circ} \mathrm{C}\right)$ below the melting range of $D, L$-lactide $\left(120-125^{\circ} \mathrm{C}\right)$ in a pilot twin-screw extruder [100]. Despite the presence of at least three points of possible attachment of lactide to the main chain of chitosan the interaction of functional groups of the polysaccharide with lactide follows the $N$-acylation pathway which is a direct consequence of the difference in the nucleophilicity of hydroxyl and amino groups of chitosan in the absence of catalysis (Fig. 1). The study of the products of reactive blending using elemental analysis and IR spectroscopy showed that the degree of substitution of the amino groups of chitosan varies from 0.19 to 0.41 and the degree of polymerization of the grafted chains of oligo $(D, L$-lactide) reaches 10 ; this was sufficient to impart affinity for organic solvents to chitosan which was expressed in the swelling of the samples in chloroform, a solvent traditional for polylactide in which the initial chitosan does not even swell. The hydrophobization of chitosan via grafting oligolactide fragments led to the manifestation of amphiphilic properties by copolymers and made it possible to use them as emulsifiers in the production of microparticles from polylactide by evaporation of a solvent from oil/water emulsions with a high yield and homogeneous surface morphology [100]. Nevertheless, copolymers mainly possess the basic properties of chitosan and are suitable for producing materials by the corresponding solution technologies. The lyophilization of solutions of samples in acetic acid and the subsequent heat treatment were used to obtain macroporous hydrogels with a high rate of enzymatic hydrolysis as compared to the initial chitosan and good biocompatibility [101]. Macroporous hydrogels with a predetermined internal structure were obtained from copolymer solutions by two-photon laser stereolithography [102].

Copolymers of chitosan with longer grafted oligolactide chains were synthesized by the solid-state coextrusion of chitosan with oligolactides $(M=5 \times$ $\left.10^{3}\right)$ [103]. In this case, the interaction of the components of reactive blend can proceed in several ways. For example, reactions can involve the terminal groups of oligolactide and lead to the acylation of the amino groups of chitosan by the terminal carboxyl 
groups of oligolactide or to the esterification of the terminal carboxyl groups of oligolactides with the hydroxyl groups of chitosan. However, taking into account a rather high degree of polymerization of the starting oligolactide $(\sim 70)$ and, accordingly, a low relative content of terminal functional groups a significant contribution to the interaction of polymers is made by reactions involving the ester bonds of oligolactide (aminolysis and transesterification). The reactions of interaction of chitosan with oligolactide should be statistical in nature, since all the considered paths of chemical interaction are possible. Accordingly, the resulting copolymers have a wide distribution both over the grafting sites and the length of grafted chains. The degree of polymerization of the grafted chain is determined by both the initial MWD of oligolactide and the intensity of the reactions of aminolysis and alcoholysis of ester bonds, as well as mechanodestruction of oligolactide during coextrusion. Solid-state reactive blending of chitosan with oligolactides with a degree of polymerization of up to 70 units affords amphiphilic systems, which, in contrast to native chitosan, form dispersions stable in chloroform and partially lose their solubility in an aqueous solvent traditional for chitosan. A set of indirect data from fractional analysis, IR spectroscopy, UV spectrophotometry, and dynamic laser light scattering suggests the presence of a fairly wide range of copolymers in the systems which differ in the number of grafting sites and the length of grafted chains. Owing to their pronounced amphiphilic properties the copolymers can be used as emulsifiers for biodegradable microparticles with a complex architecture by solvent evaporation from oil/water emulsions [104, 105]. A higher hydrophobization of chitosan, as compared to modification by interaction with lactide, made it possible to use copolymers to obtain hydrogels of a given architecture by stereolithography; the hydrogels were successfully used as scaffolds for nerve tissue regeneration [103, 106, 107].

The grafting of short and medium chains of oligolactides on chitosan gives it new properties but, in general, does not provide the necessary hydrophobicity. Solid state coextrusion with high molecular weight $\left(1.6 \times 10^{5}\right)$ polylactide samples gives rise to products that have a high affinity for organic chlorine-containing solvents and form stable dispersions in them. When studying the dispersions of samples in chloroform by dynamic laser light scattering, it was found that the size of macromolecular associates varies from $200 \mathrm{~nm}$ to $2.5 \mu \mathrm{m}$ [108]. An analysis of fractions after separation in acidic aqueous media by elemental analysis showed that about $17 \%$ chitosan in terms of the amount taken lose solubility in solvents traditional for chitosan which limits their processability by methods classical for chitosan. However, hydrophobization allows the use of standard methods for molding polyester materials which cannot be used for the production of materials from unmodified chitosan, that is, molding methods based on the affinity of copolymers for chlorine-containing solvents and their processability by melt technologies [108-110]. Hot pressed films showed good mechanical properties. For example, with a chitosan content of up to $40 \mathrm{wt} \%$ the tensile strength of the films was comparable to that of the original polylactide: 51 and $48 \mathrm{MPa}$, respectively [108].

Another significant advantage of solid-state reactive blending is the possibility to obtain multicomponent systems containing proteins or other polymers and stabilized by in situ formed graft copolymer fractions. Hybrid systems of chitosan with oligolatide/polylactides containing collagen were obtained by this method, gelatin, and polycaprolactone show promise for the production of biodegradable and biocompatible materials of various shapes for use in regenerative medicine [109-113].

\section{FUNDING}

This work was supported by the Ministry of Science and Higher Education of the Russian Federation (topic no. 0086-2019-0007).

\section{OPEN ACCESS}

This article is licensed under a Creative Commons Attribution 4.0 International License, which permits use, sharing, adaptation, distribution and reproduction in any medium or format, as long as you give appropriate credit to the original author(s) and the source, provide a link to the Creative Commons license, and indicate if changes were made. The images or other third party material in this article are included in the article's Creative Commons license, unless indicated otherwise in a credit line to the material. If material is not included in the article's Creative Commons license and your intended use is not permitted by statutory regulation or exceeds the permitted use, you will need to obtain permission directly from the copyright holder. To view a copy of this license, visit http://creativecommons.org/licenses/by/4.0/.

\section{REFERENCES}

1. D. Garlotta, J. Polym. Environ. 9, 63 (2001).

2. K. Hamad, M. Kaseem, H. W. Yang, F. Deri, and Y. G. Ko, eXPRESS Polym. Lett. 9, 435 (2015).

3. K. Madhavan Nampoothiri, N. R. Nair, and R. P. John, Bioresour. Technol. 101, 8493 (2010).

4. Polylactic Acid: PLA Biopolymer Technology and Applications, Ed. by L. T. Sin, A. R. Rahmat, and W. A. Rahman, Elsevier Science Ltd., Oxford, 2012).

5. P. A. Nikishev, Yu. A. Piskun, I. V. Vasilenko, L. V. Gaponik, P. S. Timashev, A. A. Akovantseva, and S. V. Kostyuk, Polym. Sci., Ser. B 59, 655 (2017).

6. J. D. Badia and A. Ribes-Greus, Eur. Polym. J. 84, 22 (2016).

7. I. Armentano, N. Bitinis, E. Fortunati, S. Mattioli, N. Rescignano, R. Verdejo, M. A. A. Lopez-Mancha- 
do, and J. M. M. Kenny, Prog. Polym. Sci. 38, 1720 (2013).

8. M. A. Abdel-Rahman, Y. Tashiro, and K. Sonomoto, Biotechnol. Adv. 31, 877 (2013).

9. Ó. Ögmundarson, S. Sukumara, A. Laurent, and P. Fantke, GCB Bioenergy 12, 19 (2020).

10. F. Ichikawa, M. Kobayashi, M. Ohta, Y. Yoshida, S. Obuchi, and H. Itoh, US Patent No. 5440008 (1995).

11. P. S. P. Poh, M. P. Chhaya, F. M. Wunner, E. M. DeJuan-Pardo, A. F. Schilling, J. T. Schantz, M. Van Griensven, and D. W. Hutmacher, Adv. Drug Delivery Rev. 107, 228 (2016).

12. P. Timashev, D. Kuznetsova, A. Koroleva, N. Prodanets, A. Deiwick, Y. Piskun, K. Bardakova, N. Dzhoyashvili, S. Kostjuk, E. Zagaynova, Y. Rochev, B. Chichkov, and V. Bagratashvili, Nanomedicine 11, 1041 (2016).

13. R. Auras, B. Harte, and S. Selke, Macromol. Biosci. 4, 835 (2004).

14. L. Gritsch, G. Conoscenti, V. La Carrubba, P. Nooeaid, and A. R. Boccaccini, Mater. Sci. Eng., C 94, 1083 (2019).

15. F. Molavi, M. Barzegar-Jalali, and H. Hamishehkar, J. Controlled Release 320, 265 (2020).

16. V. Lassalle and M. L. Ferreira, Macromol. Biosci. 7, 767 (2007).

17. A. Kumari, S. K. Yadav, and S. C. Yadav, Colloids Surf., B 75, 1 (2010).

18. F. Mohamed and C. F. van der Walle, J. Pharm. Sci. 97, 71 (2008).

19. A. Toncheva, M. Spasova, D. Paneva, N. Manolova, and I. Rashkov, Int. J. Polym. Mater. Polym. Biomater. 63, 657 (2014).

20. M. Santoro, S. R. Shah, J. L. Walker, and A. G. Mikos, Adv. Drug Delivery Rev. 107, 206 (2016).

21. F. Asghari, M. Samiei, K. Adibkia, A. Akbarzadeh, and S. Davaran, Artif. Cells. Nanomed., Biotechnol. 45, 185 (2017).

22. M. Jafari, Z. Paknejad, M. R. Rad, S. R. Motamedian, M. J. Eghbal, N. Nadjmi, and A. Khojasteh, J. Biomed. Mater. Res., Part B 105, 431 (2017).

23. V. Kudryavtseva, K. Stankevich, A. Gudima, E. Kibler, Y. Zhukov, E. Bolbasov, A. Malashicheva, M. Zhuravlev, V. Riabov, T. Liu, V. Filimonov, G. Remnev, H. Kluter, J. Kzhyshkowska, S. Tverdokhlebov, Mater. Des. 127, 261 (2017).

24. S. Liu, S. Qin, M. He, D. Zhou, Q. Qin, and H. Wang, Composites, Part B 199, 108238 (2020).

25. S. Sinha Ray, Acc. Chem. Res. 45, 1710 (2012).

26. S. Z. Rogovina, E. V. Prut, K. V. Aleksanyan, V. G. Krasheninnikov, E. O. Perepelitsina, D. P. Shashkin, and A. A. Berlin, Polym. Sci., Ser. B 61, 334 (2019).

27. N. E. Tsverova, A. E. Mochalova, A. G. Morozov, P. A. Yunin, L. A. Smirnova, and I. D. Grishin, Polym. Sci., Ser. B 57, 239 (2015).

28. R. Banerjee and S. S. Ray, Polym. Eng. Sci. 61, 617 (2021).

29. Chitosan: Derivatives, Composites and Applications, Ed. by S. Ahmed and S. Ikram (Wiley, Hoboken, 2017).
30. L. L. Reys, S. S. Silva, C. Oliveira, R. Lopez-Cebral, N. M. Neves, A. Martins, J. M. Oliveira, T. H. Silva, and R. L. Reis, in Encyclopedia of Marine Biotechnology (Wiley, New York, 2020), p. 2619.

31. Refining Biomass for Suitable Energy and Bioproducts, Ed. by R. P. Kumar, E. Gnasounou, J. K. Raman, and G. Baskar (Elsevier, Amsterdam, 2020).

32. I. Hamed, F. Özogul, and J. M. Regenstein, Trends Food Sci. Technol. 48, 40 (2016).

33. M. Rinaudo, Prog. Polym. Sci. 31, 603 (2006).

34. J. C. Roy, F. Salaün, S. Giraud, A. Ferri, G. Chen, and J. Guan, Solubility of Polysaccharides, Ed. by Z. Xu (InTech, Rijeka, 2017).

35. S. Z. Rogovina and T. A. Akopova, Vysokomol. Soedin., Ser. A 36, 593 (1994).

36. T. A. Akopova, A. N. Zelenetskii, and A. N. Ozerin, in Focus on Chitosan Research, Ed. by A. N. Ferguson and A. O’Neill (Nova Sci. Publ., New York, 2011), p. 223.

37. M. Hosseinnejad and S. M. Jafari, Int. J. Biol. Macromol. 85, 467 (2016).

38. J. A. Jennings, in Chitosan Based Biomaterials, Ed. by J. A. Jennings and J. D. Bumgardner (Woodhead Publ., Duxford; Cambridge; Kidlington, 2017), Vol. 1, p. 159.

39. P. Sahariah and M. Másson, Biomacromolecules 18, 3846 (2017).

40. M. Huang, E. Khor, and L.-Y. Lim, Pharm. Res. 21, 344 (2004).

41. W. S. Wan Ngah, L. C. Teong, and M. A. K. M. Hanafiah, Carbohydr. Polym. 83, 1446 (2011).

42. G. Crini and P. M. Badot, Prog. Polym. Sci. 33, 399 (2008).

43. L. Zhang, Y. Zeng, and Z. Cheng, J. Mol. Liq. 214, 175 (2016).

44. P. Venkataraman, J. Tang, E. Frenkel, G. L. McPherson, J. He, S. R. Raghavan, V. Kolesnichenko, A. Bose, and V. T. John, ACS Appl. Mater. Interfaces 5, 3572 (2013).

45. R. Yang, H. Li, M. Huang, H. Yang, and A. Li, Water Res. 95, 59 (2016).

46. E. Vunain, A. Mishra, and B. Mamba, Int. J. Biol. Macromol. 86, 570 (2016).

47. T. Arfin, in Chitosan: Derivatives, Composites and Applications, Ed. by S. Ahmed and S. Ikram (Wiley, Hoboken, 2017), Chap. 5, p. 115.

48. M. Kong, X. G. Chen, K. Xing, and H. J. Park, Int. J. Food Microbiol. 144, 51 (2010).

49. M. Aider, LWT - Food Sci. Technol. 43, 837 (2010).

50. C. Choi, J. P. Nam, and J. W. Nah, J. Ind. Eng. Chem. 33, 1 (2016).

51. S. Ahmed, A. Ali, and J. Sheikh, Int. J. Biol. Macromol. 116, 849 (2018).

52. S. Dhivya, A. Chawla, S. Saravanan, and N. Selvamurugan, Carbohydr. Polym. 151, 172 (2016).

53. R. Cheung, T. Ng, J. Wong, and W. Chan, Mar. Drugs 13, 5156 (2015).

54. S. Saravanan, R. S. Leena, and N. Selvamurugan, Int. J. Biol. Macromol. 93, 1354 (2016).

55. S. Ahmed and S. Ikram, Achiev. Life Sci. 10, 27 (2016). 
56. I. Y. Kim, S. J. Seo, H. S. Moon, M. K. Yoo, I. Y. Park, B. C. Kim, and C. S. Cho, Biotechnol. Adv. 26, 1 (2008).

57. A. Anitha, S. Sowmya, P. T. T. S. S. Kumar, S. Deepthi, K. P. P. Chennazhi, H. Ehrlich, M. Tsurkan, and R. Jayakumar, Prog. Polym. Sci. 39, 1644 (2014).

58. L. Casettari and L. Illum, J. Controlled Release 190, 189 (2014).

59. V. Patrulea, V. Ostafe, G. Borchard, and O. Jordan, Eur. J. Pharm. Biopharm. 97, 417 (2015).

60. R. Jayakumar, D. Menon, K. Manzoor, S. V. Nair, and H. Tamura, Carbohydr. Polym. 82, 227 (2010).

61. S. M. Ahsan, M. Thomas, K. K. Reddy, S. G. Sooraparaju, A. Asthana, and I. Bhatnagar, Int. J. Biol. Macromol. 110, 97 (2018).

62. T. Jiang, M. Deng, R. James, L. S. Nair, and C. T. Laurencin, Acta Biomater. 10, 1632 (2014).

63. V. Balan and L. Verestiuc, Eur. Polym. J. 53, 171 (2014).

64. M. B. Dowling, R. Kumar, M. A. Keibler, J. R. Hess, G. V. Bochicchio, and S. R. Raghavan, Biomaterials 32, 3351 (2011).

65. K. Delmar and H. Bianco-Peled, Carbohydr. Polym. 136, 570 (2016).

66. L. Racine, I. Texier, and R. Auzély-Velty, Polym. Int. 66, 981 (2017).

67. E. P. de Azevedo, Int. J. Pharm. Pharm. Sci. 7 (12), 8 (2015).

68. S. Van Vlierberghe, P. Dubruel, and E. Schacht, Biomacromolecules 12, 1387 (2011).

69. K. N. Bardakova, T. A. Akopova, A. V. Kurkov, G. P. Goncharuk, D. V. Butnaru, V. F. Burdukovskii, A. A. Antoshin, I. A. Farion, T. M. Zharikova, A. B. Shekhter, V. I. Yusupov, P. S. Timashev, and Y. A. Rochev, Mar. Drugs 17, 48 (2019).

70. K. Kalantari, A. M. Afifi, H. Jahangirian, and T. J. Webster, Carbohydr. Polym. 207, 588 (2019).

71. S. A. Agnihotri, N. N. Mallikarjuna, and T. M. Aminabhavi, J. Controlled Release 100, 5 (2004).

72. O. I. Bogdanova and S. N. Chvalun, Polym. Sci., Ser. A 58, 629 (2016).

73. V. K. Thakur and M. K. Thakur, ACS Sustainable Chem. Eng. 2, 2637 (2014).

74. I. A. Farion, V. F. Burdukovskii, B. C. Kholkhoev, P. S. Timashev, and R. K. Chailakhyan, eXPRESS Polym. Lett. 12, 1081 (2018).

75. S. Dimassi, N. Tabary, F. Chai, N. Blanchemain, and B. Martel, Carbohydr. Polym. 202, 382 (2018).

76. C. Bhavsar, M. Momin, S. Gharat, and A. Omri, Expert. Opin. Drug. Delivery 14, 1189 (2017).

77. D. Kumar, S. Gihar, M. K. Shrivash, P. Kumar, and P. P. Kundu, Int. J. Biol. Macromol. 163, 2097 (2020).

78. N. A. Negm, H. H. H. Hefni, A. A. A. Abd-Elaal, E. A. Badr, and M. T. H. Abou Kana, Int. J. Biol. Macromol. 152, 681 (2020).

79. A. V. Pestov, Yu. O. Privar, E. B. Modin, A. Yu. Ustinov, and S. Yu. Bratskaya, Polym. Sci., Ser. B 58, 730 (2016).
80. L. A. Nud'ga, V. A. Petrova, V. I. Frolov, I. V. Gofman, A. V. Masluakova, and N. M. Zhuravleva, Polym. Sci., Ser. A 47, 90 (2005).

81. A. E. Mochalova and L. A. Smirnova, Polym. Sci., Ser. B 60, 131 (2018).

82. T. S. Demina, T. A. Akopova, L. V. Vladimirov, A. N. Shchegolikhin, A. S. Kechek'yan, N. S. Perov, A. O. Chernyshenko, and A. N. Zelenetskii, Polym. Sci., Ser. B 53, 358 (2011).

83. N. V. Minaev, T. S. Demina, S. A. Minaeva, A. A. Dulyasova, E. D. Minaeva, S. A. Gonchukov, T. A. Akopova, and P. S. Timashev, Bull. Russ. Acad. Sci. Phys. 84, 1315 (2020).

84. T. S. Demina, A. B. Gilman, and A. N. Zelenetskii, High Energy Chem. 51, 302 (2017).

85. L. Li, S. Ding, and C. Zhou, J. Appl. Polym. Sci. 91, 274 (2004).

86. J. Bonilla, E. Fortunati, M. Vargas, A. Chiralt, and J. M. Kenny, J. Food Eng. 119, 236 (2013).

87. S. Singh, G. Singh, C. Prakash, S. Ramakrishna, L. Lamberti, and C. I. Pruncu, Polym. Test. 89, 106722 (2020).

88. J. Xu, J. Zhang, W. Gao, H. Liang, H. Wang, and J. Li, Mater. Lett. 63, 658 (2009).

89. M. Râpă, A. C. Miteluţ, E. E. Tănase, E. Grosu, P. Popescu, M. E. Popa, J. T. Rosnes, M. Sivertsvik, R. N. Darie-Niţă, and C. Vasile, Composites, Part B 102, 112 (2016).

90. Y. Liu, S. Wang, and R. Zhang, Int. J. Biol. Macromol. 103, 1130 (2017).

91. V. M. Correlo, L. F. Boesel, M. Bhattacharya, J. F. Mano, N. M. Neves, and R. L. Reis, Mater. Sci. Eng., A 403, 57 (2005).

92. G. Li, Y. Zhuang, Q. Mu, M. Wang, and Y. Fang, Carbohydr. Polym. 72, 60 (2008).

93. G. E. Luckachan and C. K. S. Pillai, Carbohydr. Polym. 64, 254 (2006).

94. H. Feng and C.-M. Dong, Biomacromolecules 7, 3069 (2006)

95. Y. Liu, F. Tian, and K. A. Hu, Carbohydr. Res. 339, 845 (2004).

96. Y. Wu, Y. Zheng, W. Yang, C. Wang, J. Hu, and S. Fu, Carbohydr. Polym. 59, 165 (2005).

97. N. Bhattarai, H. R. Ramay, S.-H. Chou, and M. Zhang, Int. J. Nanomed. 1, 181 (2006).

98. P. E. Goryunova, S. S. Sologubov, A. V. Markin, N. N. Smirnova, S. D. Zaitsev, N. E. Silina, and L. A. Smirnova, Thermochim. Acta 659, 19 (2018).

99. N. E. Silina, A. G. Morozov, E. E. Gornostaeva, L. A. Smirnova, and S. D. Zaytsev, Polym. Sci., Ser. B 59, 551 (2019).

100. T. S. Demina, T. A. Akopova, L. V. Vladimirov, A. N. Zelenetskii, E. A. Markvicheva, and C. Grandfils, Mater. Sci. Eng., C 59, 333 (2016).

101. T. S. Demina, D. S. Zaytseva-Zotova, T. A. Akopova, A. N. Zelenetskii, and E. A. Markvicheva, J. Appl. Polym. Sci. 134, 17 (2017).

102. T. S. Demina, K. N. Bardakova, E. A. Svidchenko, N. V. Minaev, G. I. Pudovkina, M. M. Novikov, D. V. Butnaru, N. M. Surin, T. A. Akopova, 
V. N. Bagratashvili, A. N. Zelenetskii, and P. S. Timashev, High Energy Chem. 50, 389 (2016).

103. T. Demina, K. Bardakova, N. Minaev, E. Svidchenko, A. Istomin, G. Goncharuk, L. Vladimirov, A. Grachev, A. Zelenetskii, P. Timashev, and T. Akopova, Polymers 9, 302 (2017).

104. T. S. Demina and C. Grandfils, Mater. Today: Proc. 12, 93 (2019).

105. T. S. Demina, C. Sevrin, C. Kapchiekue, T. A. Akopova, and C. Grandfils, Macromol. Mater. Eng. 304, 1900203 (2019).

106. E. A. Grebenik, A. M. Surin, K. N. Bardakova, T. S. Demina, N. V. Minaev, N. N. Veryasova, M. A. Artyukhova, I. A. Krasilnikova, Z. V. Bakaeva, E. G. Sorokina, D. P. Boyarkin, T. A. Akopova, V. G. Pinelis, and P. S. Timashev, Biomed. Mater. 15, 015011 (2020).

107. V. A. Revkova, E. A. Grebenik, V. A. Kalsin, T. S. Demina, K. N. Bardakova, B. S. Shavkuta, P. A. Melnikov, E. M. Samoilova, M. A. Konoplyannikov, Y. M. Efremov, C. Zhang, T. A. Akopova, A. V. Troitsky, P. S. Timashev, and V. P. Baklaushev, Tissue Eng., Part A 26, 953 (2020).
108. T. A. Akopova, T. S. Demina, A. N. Shchegolikhin, T. S. Kurkin, C. Grandfils, N. S. Perov, A. S. Kechekyan, and A. N. Zelenetskii, Int. J. Polym. Sci. 2012, 1 (2012).

109. T. S. Demina, M. G. Drozdova, C. Sevrin, P. Compere, T. A. Akopova, E. Markvicheva, and C. Grandfils, Molecules 25, 1949 (2020).

110. T. Demina, D. Zaytseva-Zotova, M. Yablokov, A. Gilman, T. Akopova, E. Markvicheva, and A. Zelenetskii, Surf. Coat. Technol. 207, 508 (2012).

111. O. A. Romanova, T. H. Tenchurin, T. S. Demina, E. V. Sytina, A. D. Shepelev, S. G. Rudyak, O. I. Klein, S. V. Krasheninnikov, E. I. Safronova, R. A. Kamyshinsky, V. G. Mamagulashvili, T. A. Akopova, S. N. Chvalun, and A. A. Panteleyev, Cell Proliferation 52, 12598 (2019).

112. T. S. Demina, A. S. Kuryanova, N. A. Aksenova, A. G. Shubnyy, T. N. Popyrina, Y. V. Sokovikov, E. V. Istranova, P. L. Ivanov, P. S. Timashev, T. A. Akopova, RSC Adv. 9, 37652 (2019).

113. T. S. Demina, A. S. Kuryanova, P. Y. Bikmulina, N. A. Aksenova, Y. M. Efremov, Z. I. Khaibullin, P. L. Ivanov, N. V. Kosheleva, P. S. Timashev, and T. A. Akopova, Polymers 12, 1911 (2020). 